\title{
総義歯装着者の厚さの弁別能に関する研究
}

\author{
岡根秀明高木道弘 \\ 長沢亨津留宏道
}

\section{Thickness Discrimination in Complete Denture Wearers}

\author{
Hideaki Okane, Michihiro Takagi, \\ Tooru Nagasawa and Hiromichi Tsuru
}

緒言

咀嚼運動に際して口腔粘膜は常に食物に上る刺激を受 け，この刺激によつて䫟の動きは反射的に調整されてい $る^{11}$.すなわち，咀嚼筋の活動は高位の中枢からの支配 を受ける一方、口腔内の感覚によつて複雑な反射的調節 を受けている2)。したがつて， 口腔感覚は咀獣運動を円 滑に行う上に重要な因子の1つであると考えられる。

義歯の咀嚼機能をよくするためには出来るだけ口腔感 覚を阻害しないように配慮して作製することが必要であ る.このようなことから，義菨装着者の口腔感覚につい て分析することは有意義であるといえよう.

今回は, 口腔感覚のうち物質の厚さの弁別能に関して 実験を行つたが，従来より義歯装着者の厚さの弁別能に 関しては, Manly ら $\left(1952^{3)}\right)$, 渡辺 $\left(1960^{4,5)}\right)$, Siirilä and Laine $\left(1972^{6)}\right)$, 森本ら $\left(1976^{7)}\right)$, 高木ら $\left(1977^{8)}\right)$ 等の多数の報告がある。

しかしながら天然菊と総義歯の厚さの弁別能に差がな いとするもの ${ }^{3,6 \sim 8)}$ と, 義歯の弁別能が劣るとするものが あり ${ }^{4,5)}$ ，研究者によつて報告に差があるのが現状であ る. さらに総義歯装着者の場合は顎堤の条件，義歯経験 の有無なども厚さの弁別に関係すると思われるが不明で ある.

そこで我々は改めて総義歯装着者の厚さの弁別能が天 然歯列者のそれと相違があるかどうか，また咬合部位に

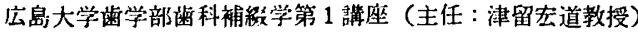
Department of Complete and Partial Denture Pros. thodontics, Hiroshima University School of Dentistry (Chief : Prof. Hiromichi Tsuru)

昭和 53 年 2 月 28 日受付
よる差や被験者の年齢, 性別, 䪽堤状態, 義歯経験年数 などの条件によつて相違があるかどうかを検討する目的 で本研究を行つた.

\section{実験材料ならびに実験方法}

\section{1. 被 験 者}

広島大学歯学部付属病院補緅科で総義歯を装着した患 者の中から義歯の適合が良好で， 口腔および全身状態に 異常所見がなく，実験に協力的な，年龉 44 歳から 79 歳 の者 12 名を選んだ。それら被験者は顎堤状態の良好な 者 6 名，不良の者 6 名で，また総義歯経験年数を後述す るような 4 段階に 3 名ずつ分類できる者である（表 1 ）.

なお，顎堤の状態は Kapur ${ }^{9)}$ の方法によつて分類を 行つた.

以上の他に比較実験として，年齡 25 歳から 28 歳で, over bite が $2.0 \mathrm{~mm}$ 以下の健全天然歯列を有する男子 3 名を選んで実験を行つた.

\section{2. 実験材料}

実験には厚さ $0.2 \mathrm{~mm}$ から $0.8 \mathrm{~mm}$ まで $0.1 \mathrm{~mm}$ 間 隔の 7 枚の JIS 規格銅製すきまゲージ（永并ゲージ製作 所製）をテスト板として用い， $0.5 \mathrm{~mm}$ を基準板とした (図 1 ).

咬む部位は習慣性咀嚼側の中切歯部, 第 2 小臼歯部, および第 1 大臼歯部の 3 力所とした. テスト板を挿入す る深さが実験ごとに変化すると厚さの判定に差が生じる 可能性があるので，前歯部はテスト板の先端から $5 \mathrm{~mm}$ の部分を切端咬合の状態で咬ませ， 臼歯部はテスト板を 前方 $45^{\circ}$ の方向から抙入した時, 煩側咬頭が先端から 10 $\mathrm{mm}$ の部分を咬むように規定した. 
表 1 各被験者 (総義歯装着者) の条件

\begin{tabular}{|c|c|c|c|c|c|c|}
\hline Subject & $\operatorname{sex}$ & age & $\begin{array}{l}\text { full denture } \\
\text { experience }\end{array}$ & $\begin{array}{l}\text { ridge } \\
\text { upper }\end{array}$ & $\begin{array}{l}\text { condition } \\
\text { lower }\end{array}$ & $\begin{array}{c}\text { Kapur's } \\
\text { score }\end{array}$ \\
\hline 1 & f & 44 & no experience & G & G & 19 \\
\hline 2 & $f$ & 63 & more than $10 y$ & $\mathrm{G}$ & G & 19 \\
\hline 3 & $\mathbf{m}$ & 77 & no experience & G & $G$ & 18 \\
\hline 4 & f & 61 & $3 y$ & G & G & 18 \\
\hline 5 & m & 72 & more than $10 y$ & G & G & 20 \\
\hline 6 & $\mathbf{m}$ & 63 & $7 \sim 8 y$ & G & G & 20 \\
\hline 7 & $f$ & 56 & $3 y$ & $\mathrm{P}$ & $\mathrm{P}$ & 9 \\
\hline 8 & f & 62 & $7 \sim 8 y$ & G & $\mathrm{P}$ & 13 \\
\hline 9 & f & 45 & no experience & $\mathrm{P}$ & $\mathrm{P}$ & 9 \\
\hline 10 & $\mathrm{f}$ & 65 & $7 \sim 8 y$ & $\mathrm{~S}$ & $P$ & 12 \\
\hline 11 & $\mathrm{~m}$ & 79 & more than $10 y$ & G & $\mathrm{P}$ & 13 \\
\hline 12 & f & 52 & $1 y$ & S & $\mathrm{P}$ & 12 \\
\hline \multicolumn{3}{|c|}{$\begin{array}{l}\mathrm{m}: \text { male } \\
\mathrm{f}: \text { female }\end{array}$} & y : year & \multicolumn{3}{|c|}{$\begin{array}{l}\text { S: Satisfactory } \\
\text { P : Poor }\end{array}$} \\
\hline
\end{tabular}

臼歯部で咬んだ場合も前歯部における切端咬合の高さ と同一になるように調整した咬合面板を常温重合レジン で作製し，それを上下臼歯部咬合面におき，咬合時に平 面で接するように調整して実験を行つた（図 2 ）.

被験者は眼を閉じさせ，テスト板が口唇，舌などに触 れないように注意した。

\section{3. 実験方法}

基準の厚さ $0.5 \mathrm{~mm}$ のテスト板を $4 \sim 5$ 回軽くタッピ ングさせて厚さを覚えさせ，ただちに別のテスト板を同 様に咬ませて後者が前者に比較して「厚い」か「薄い」 か「同じ」かを返答させテストチャート（表 2）に記録 した. 基準の厚さのテスト板は毎回咬ませ, 次に判定さ せるテスト板をアトランダムに与えたが, $0.2 \mathrm{~mm}$ から $0.8 \mathrm{~mm}$ までの 7 種類のテスト板をそれぞれ 1 度ずつ判 定させてから次の回に移行するようにした.

実験は静かな室内で患者を uplight position にした 治療椅子に座らせて行つた. また実験時問は全被験者 共, 尽食前 1〜2 時間に統一した.

実験の順序は前歯部，小臼歯部，大臼歯部を被験者間 でアトランダムに行い, 各部位ごとに最初 1 度ずつ練習 させた.

\section{4. 実験時期}

被験者のうち 4 名は義歯装着直後に, 残り 8 名のうち 4 名は装着後 3 日から 1 週閒以内に, 他の 4 名は装着後 3 カ月以上経過し，新義歯に慣れたと判断された後に実 験を行つた. 各グループにおいては顎堤状態の良好な者

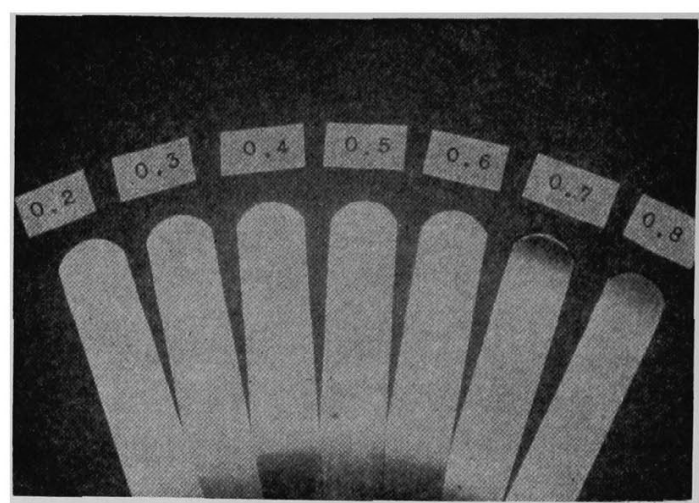

図 1 テスト板

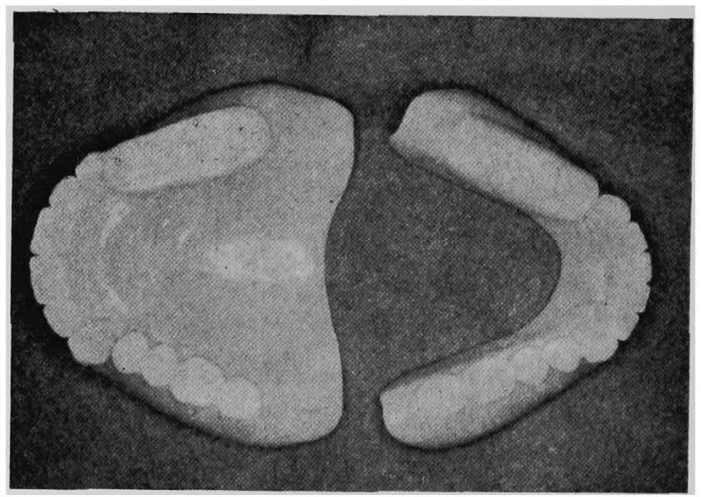

図 2 咬合面板を装着した上下総義蔝

と不良な者が 2 名ずつとなるように配虑した。

装着後 1 週間以内に実験を行つた 8 名のうち，顎堤状 態が良好な者 4 名については同時に旧義歯についても （前歯部のみ）実験を行い，新義歯の結果と比較した.

\section{5. 実験操作の回数}

より正確なデータを得るためには，一般に実験回数を 多くする方が良いが, 本研究の場合, 回数を多くし過ぎ ると実験に対する学習効果が加わる可能性があること, 逆に被験者が実験に飽きて非協力的となり，データの信 頼性が低下すること, 被験者の疲労が弁別能を低下させ ることの 3 点を考虑しなければならない.

予備実験を行つた結果（図 3 ），および高木ら 然歯列者について実験回数と弁別能を検討した結果によ り，各部位について実験サイクル（7 種のテスト板を各 1 度ずつ判定）を 5 回以内とすれば，弁別能の変動が少 ないと思われた（最大 $\pm 4.9 \%$ 小臼歯部）.

そこで 1 被験者につき各部位 35 回ずつ, 合計 105 回 の実験操作にとどめることにした. 
表 2 実験結果の記録に用いたチャート

\begin{tabular}{ll}
\hline \\
Patient \\
Denture condition \\
Denture experience \\
Denture-bearing tissues \\
Prefer red chewing side \\
Patient's evaluation
\end{tabular}

Patient's evaluation

Remarks

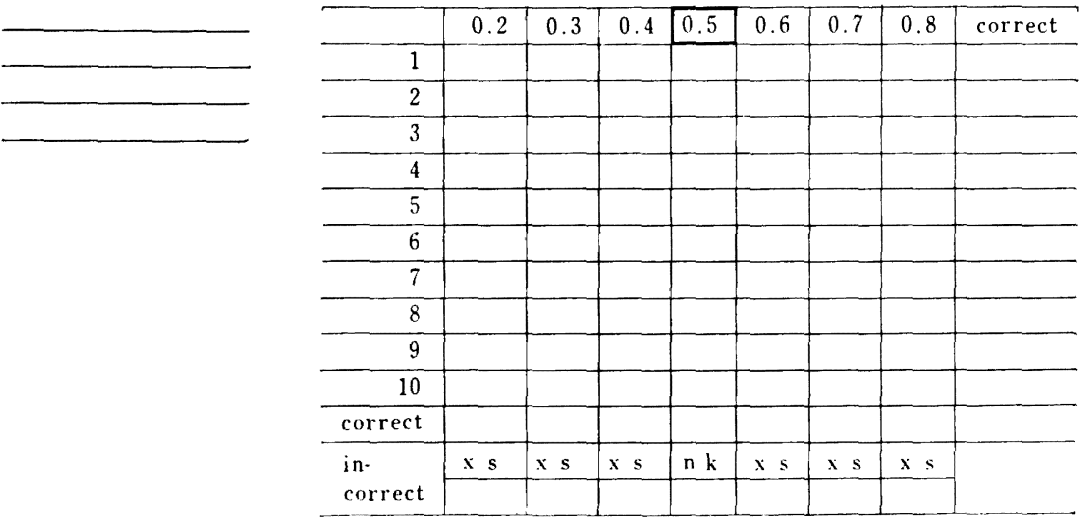

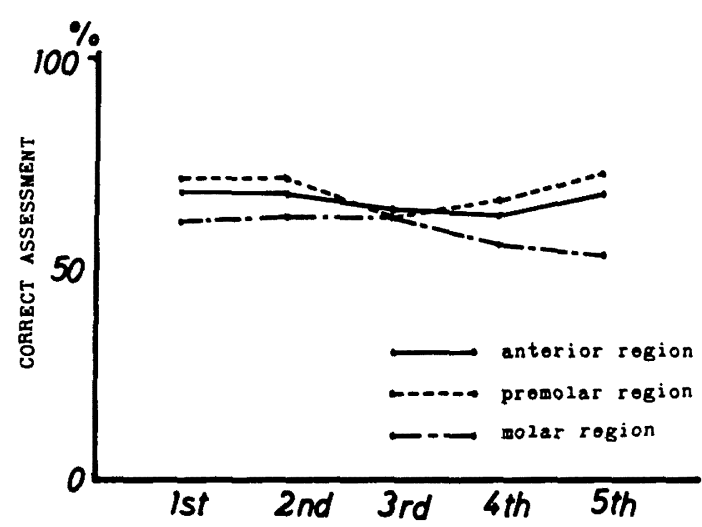

図 3 実験の繰り返しによる弁別能の差 5 回までの実験の繰り返しでは弁別能に差が認められない。

\section{実験結果}

総義歯装着者 12 名について 1,400 回テストを行い, 天然歯列者 3 名については 315 回テストを行い，以下の 分析を行つた.

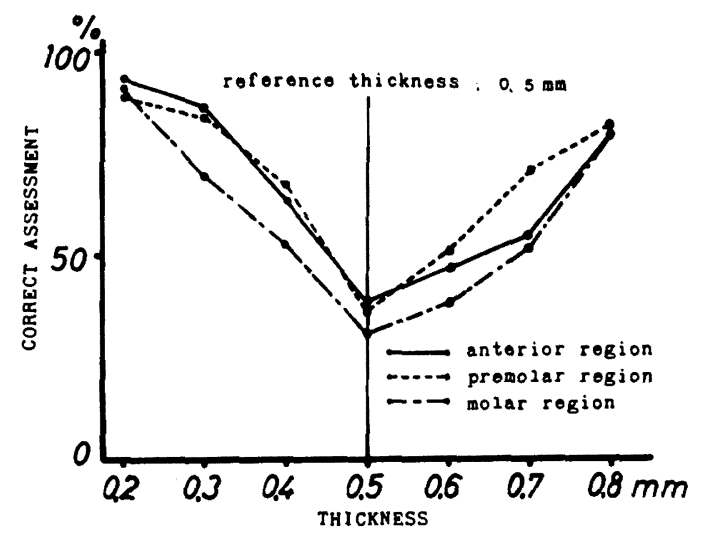

図 4 弁別のパターン

基準より溥いテスト板は并別能がが高く，愿いテスト板は 升別能が低い。この傾向は前歯部, 小臼歯部, および大臼 歯部のいずれの部位でも見られる。

\section{1. 弁別のパターン}

図 4 は前歯部，小臼歯部，大臼歯部それぞれの部位に おける総義歯装着者の平均正解率を各テス卜板の厚さ別 にグラフに表わしたものである、いずれの厚さにおいて も大臼歯部の正解率が最も低かつた．前歯部と小臼歯部 


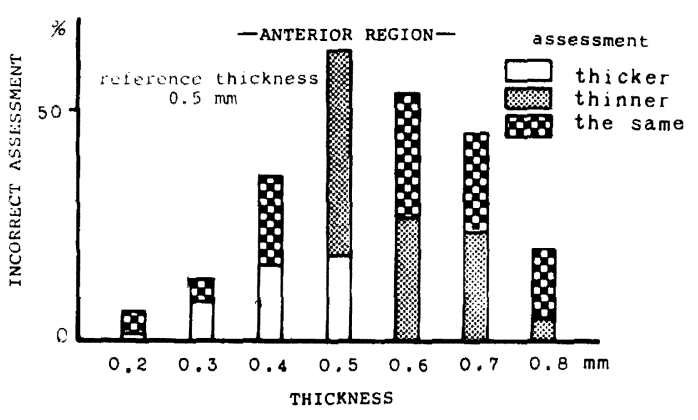

図 5 譟つて弁別した割合い上ぞの内谷（前蒾部）

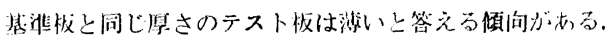

は基準より薄いテスト板を咬んだ場合の正解率に差はな いが、基準より厚いテスト板では小臼歯部の方が高い正 解率を示した、いずれの部位に扔いても，基準より薄い テスト板の方が基準より厚いテスト板より宿い正解率を 示し，基準と同じ厚さ $0.5 \mathrm{~mm}$ のテスト板の正解率は 最も低かつた.

\section{2. 各種厚さの䛃り率とその内容}

図 5 は前歯部における総義菊装着者の誤り率とその内 容を各テスト板の将さ別に示したものである，基準より 薄いテス卜板の場合, 誤つた答の内容は「厚い」と「同 じ」の 2 種類に分けられる. 同栐に基準と闹じ厚さのテ スト板では，誤つた答は「薄い」と「果い」であり，基 準より厚いテスト板の場合は「薄い」と「同じ」であ る.図 5 に示したように，基準より㸝いテスト板の方が 誤り率が高かつた，基準と同じ厚さのテスト板では「厚 い」と答えるより「薄い」と答える方が有意に多かつ た.これは高木ら ${ }^{8,10)}$ の結果と同じである，小臼歯部， 大曰歯部もほぼ同様の結果を示した。

\section{3. 咬む部位と正解率}

図 6 は前歯部，小四歯部，大臼歯部における全正解率 の総義歯装着者の平均值と標準偏差を示したものであ る. 小囦歯部の正解率が最も宫く $(69.8 \% \pm 14.5 \%)$, 前歯部 $(66.2 \% \pm 13.5 \%)$, 大臼歯部 $(59.8 \% \pm 12.5 \%)$ の順であつた．小四歯部と前歯部，小臼歯部と大臼歯 部，前歯部と大曰歯部の閒には統計学的有意差があつた $(\mathrm{P}<0.05)$.

仪 7 は天然歯列者の前歯部，小曰蒾部，大曰蔽部にお ける全正解率の平均值と標準偏差を示したものである. 前歯部の正解率が最も高く $(79.1 \% \pm 3.3 \%)$ ，小臼歯部 $(71.4 \% \pm 8.6 \%)$, 大臼歯部 $(66.7 \% \pm 9.2 \%)$ の順であ

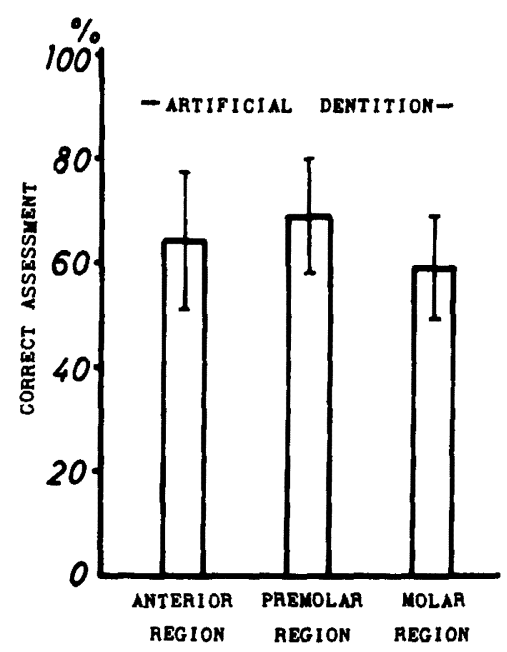

図 6 咬む部位に上る升別能の違い（総義歯） 小臼歯部の升别能が最も滈い。

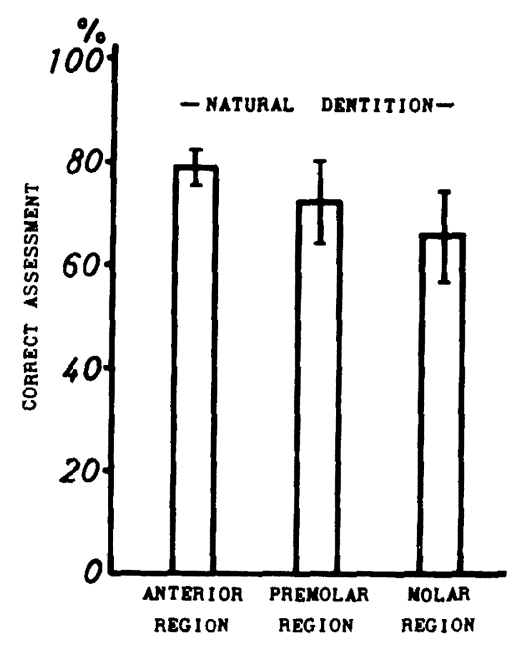

図 7 咬む部位に上る゙我別能の違い(天然歯)

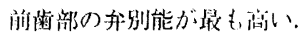

つた.

\section{4. 被験者の主観と実験結果}

実験が終ればただちに被験者に前歯部，小臼歯部，大 臼歯部の 3 つの部位について, 弁別しやすかつたと感じ た順を答えさせ，実験の結果と比較した．表 3 は総義菌 装着者の結果を示したものである. 縦の欄は被験者の主

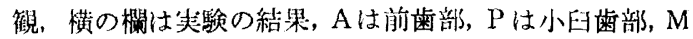
は大臼歯部，*印1 つは被験者 1 人を示す.

表 3 に示したように総義歯装着者の主観は 3 種類, 実 験の結果は 6 種類に分かれた. 小臼歯部が最も弁別しや 
表 3 被倹者（総義歯装着者）の主観と実験結果の相閔

12 名中 9 名の被験者においた，垠も弁別しやすいと答えた部位と奏験の結果最も弁別能が滈かつた部位とが一致した。

\begin{tabular}{|c|c|c|c|c|c|c|c|c|}
\hline subjects $\begin{array}{c}\text { test } \\
\text { evaluation }\end{array}$ & $\mathrm{A}>\mathrm{P}>\mathrm{M}$ & $\mathrm{A}>\mathrm{M}>\mathrm{P}$ & $\mathrm{A}>\mathrm{P}=\mathrm{M}$ & $\mathrm{P}>\mathrm{A}>\mathrm{M}$ & $\mathrm{P}>\mathrm{M}>\mathrm{A}$ & $\mathrm{P}>\mathrm{A}=\mathrm{M}$ & & \\
\hline $\mathrm{A}>\mathrm{P}>\mathrm{M}$ & $*$ & $*$ & & & & & 2 & \multirow{2}{*}{2} \\
\hline $\mathrm{A}>\mathrm{M}>\mathrm{P}$ & & & & & & & 0 & \\
\hline $\mathrm{P}>\mathrm{A}>\mathrm{M}$ & $*$ & & & $*$ & $* *$ & & 4 & \multirow{2}{*}{10} \\
\hline \multirow[t]{3}{*}{$\mathrm{P}>\mathrm{M}>\mathrm{A}$} & & & $* *$ & $* *$ & * & $*$ & 6 & \\
\hline & 2 & 1 & 2 & 3 & 3 & 1 & \multirow{2}{*}{\multicolumn{2}{|c|}{12}} \\
\hline & \multicolumn{3}{|c|}{5} & \multicolumn{3}{|c|}{7} & & \\
\hline-2. & $\begin{array}{l}\text { A : Anterio } \\
\mathrm{P}: \text { Premol } \\
\mathrm{M}: \text { Molar }\end{array}$ & $\begin{array}{l}\text { region } \\
\text { region } \\
\text { egion }\end{array}$ & $*:$ one $s$ & whject & & & & \\
\hline
\end{tabular}

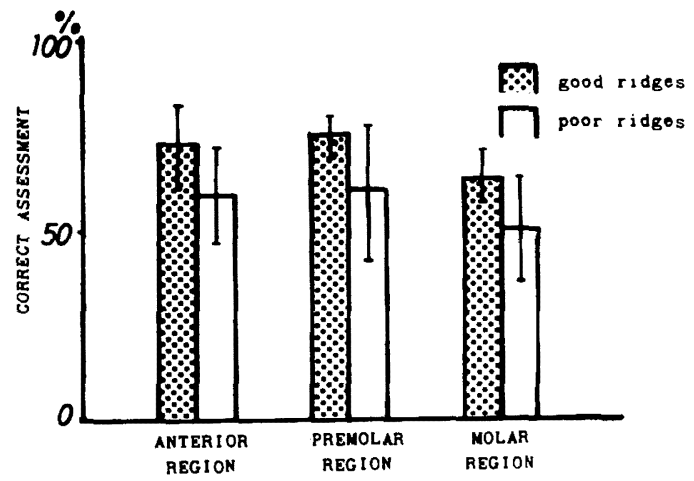

図 8 颌堤状態の良好な者と不良な者の弁別能 颁堤状態の良好な者の方が不良な者より卉别能が高い。 両者共小臼崡部の升別能が最も滈い.

すいと答えた者は 12 名中 10 名（83.3\%）に達し，その うちの 7 名（全体の $58.3 \%$ ）については実験の結果も小 臼歯部の正解率が最も高かつた。しかし，主観における 3つの部位の弁別しやすさの順と実験結果における $3 つ$ の部位の正解率の高かつた順とが完全に一致した者はわ ずか 3 名（25\%）であつたたただし，最も弁別しやすい と答えた部位と実験の結果, 最も正解率の高かつた部位 とが一致した者は 9 名 (75\%) に達した.

天然歯列者はいずれも前歯部が最も弁別しやすく, 次 いで小田歯部，大臼菌部の順であると答え，実験結果と も完全に一致した.

\section{5. 頻堤の状態と弁別能}

図 8 は顎堤の状態の良好な者 ( 6 名) と不良な者 ( 6 名) について，それぞれの平均正解率と標準偏差を前歯部,

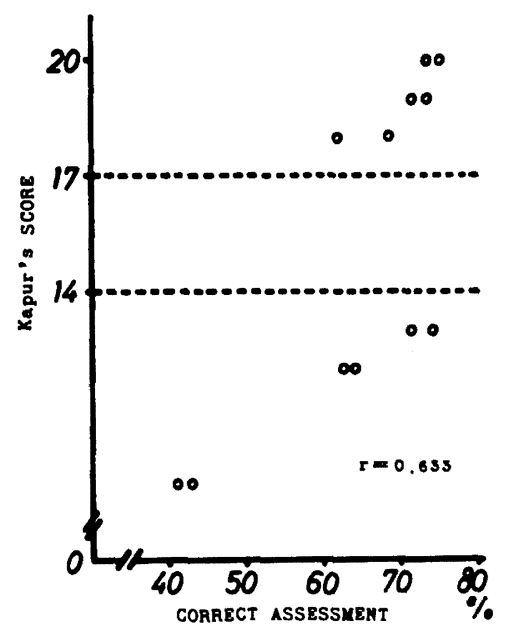

図 9 影堤の状態と弁別能の相閔 Kapur's score $>17$ Good $17 \geqq$ Kapur's score $\geqq 14$ Satisfactory $14>$ Kapur's score Poor Good ridge の者は弁別能が滦い

小臼歯部，大臼歯部に分けて示したものである. グラフ に示した通り，いずれの部位でも影堤状態が良い者の方 が正解率が高かつた．前歯部，大鼠部には統計学的有 意差があつた $(\mathrm{P}<0.05)$.

小曰歯部は 2 つの標本集団の分散の差が大きいため検 定が出来なかつた。

図 9 は㴦堤状態と全正解率の相関図である. 縦軸は額 堤の状態の良好さを表わす Kapur ${ }^{9)}$ の指数である. Score $>17$ が Good, $17 \geqq$ score $\geqq 14$ が Satisfactory, 14>score が poor を表わす. 横軸は各被験者の正解率 


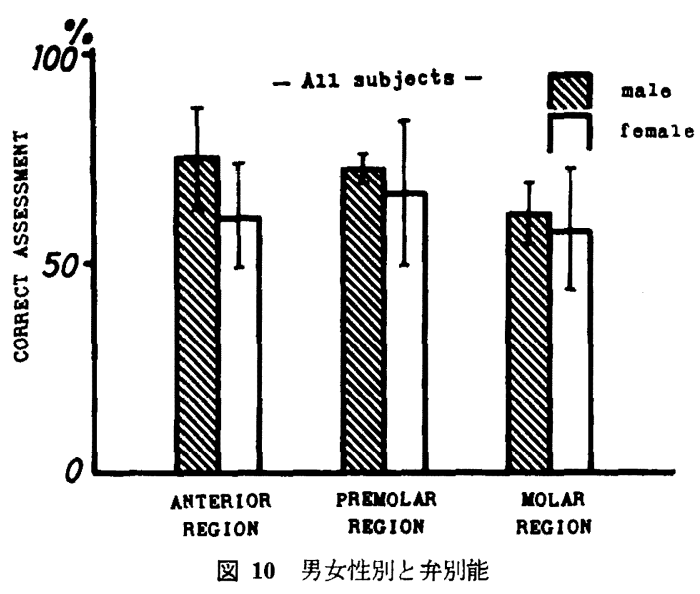

見か十上，男性の力が乎別能が高いように思われる。

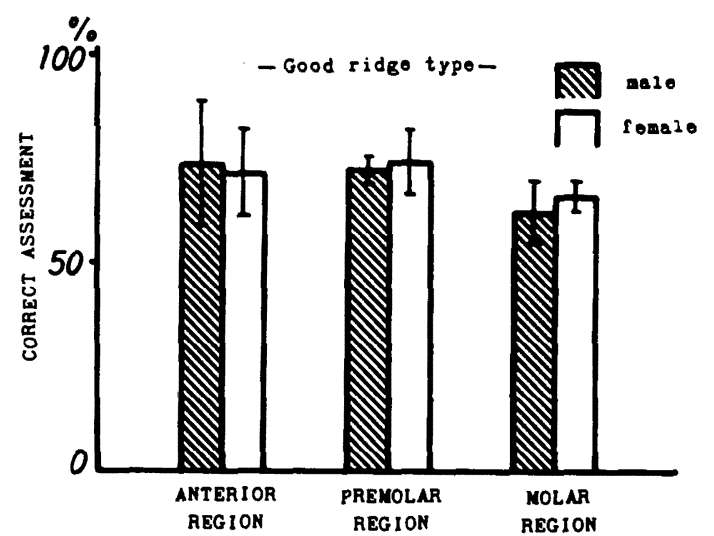

図 11 男女性別と升別能(顎堤状態の良い者) 男女の弁別能には差は認められない。

である。

相関係数 0.633 で, 統計学的に有意の正の相関関倸が あることが判明した $(\mathrm{P}<0.05)$.

\section{6. 男女性別と弁別能}

図 10 は総義歯装着者（男性 4 名, 女性 8 名) を男女 に分けて, それぞれの平均正解率と標準偏差を前歯部, 小臼歯部，大臼菊部について示したものである. いずれ の部位においても男性の方が女性より高い正解率を示 し，見かけ上は弁別能に性別による差が存在するように 思われた。これは今回用いた被験者の場合, 䫈堤状態の 覀い者のグループに女性が多かつたことが原因であろう と考えられたため，額堤状態の良好な男女 3 名ずつのグ ループについて男女別の平均正解率と標準偏差を図 11 に示した.この結果, 男女の問にはほとんど差は認めら

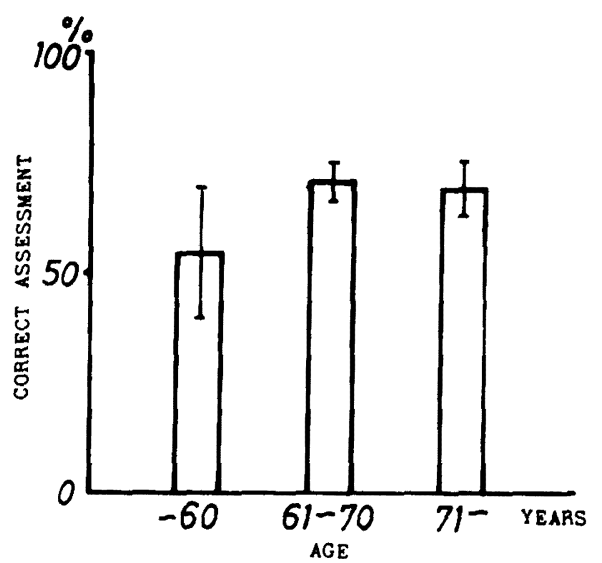

図 12 年龄と弁別能

年龄の若い者の方がむしろ弁別能が低い.

れなかった。

\section{7. 年齢と弁別能}

図 12 は被験者の年龄を 60 歳以下，61 70 歳, 71 歳 以上に分類し，それぞれのグループの平均正解率と標準 偏差を示したものである. 年齢を以上の 3 グループに分 類すれば、それぞれのグループの被験者数は 4 名ずつ々 なる.グラフに示したように 61〜0 歳のグループの正 解率が最も高く, 次いで 71 歳以上, 60 歳以下の順であ り，ばらつきの大きさもこの順であつた. この結果によ れば見かけ上年齢が増すと弁別能が向上するようように 思われた.

\section{8. 総義歯使用経験と正解率}

図 13 は総義歯経験年数を経験なし，5年以内の経験, $5 \sim 10$ 年の経験, 10 年以上の経験の 4 つのグループに分 け，それぞれのグループの平均正解率と標準偏差を示し たものでる. 経験年数を以上のように分類すれば，それ ぞれのグループの被験者数は 3 名ずつとなる. グラフに 示したように経験年数が多くなるにしたがつて正解率は 高くなり,ばらつきも少なくなつた，末経験および 1〜5 年のグループと $5 \sim 10$ 年および 10 年以上のグループの 間には統計学的有意差があつた $(\mathrm{P}<0.05)$.

\section{9. 新義㐘装着期間と正解率}

図 14 は新義歯を装着した值後に実験を行ったグルー プ、装着後 3 日から 1 週間以内に実験を行ったグルー プ，および装着後 3 カ月以上経過して完全に義歯に慣れ たと判断されてから実験を行つたグループのそれぞれの 


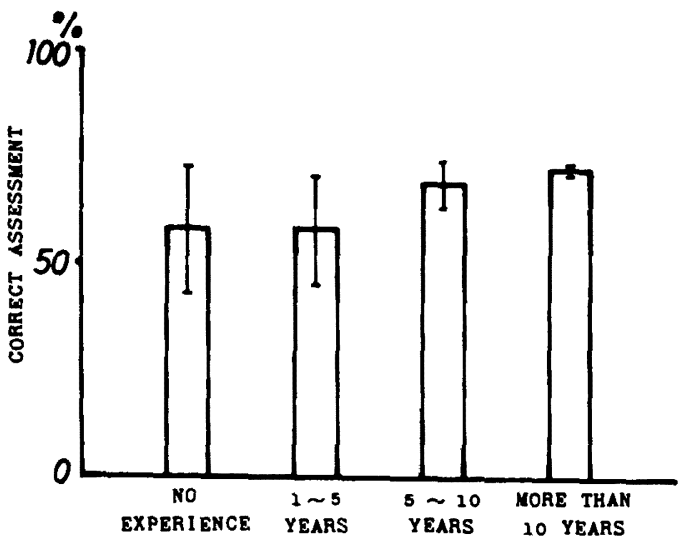

图 13 総義蔽経験年数と开別能 総義歯経験年数が多い程, 弁別能は高い。

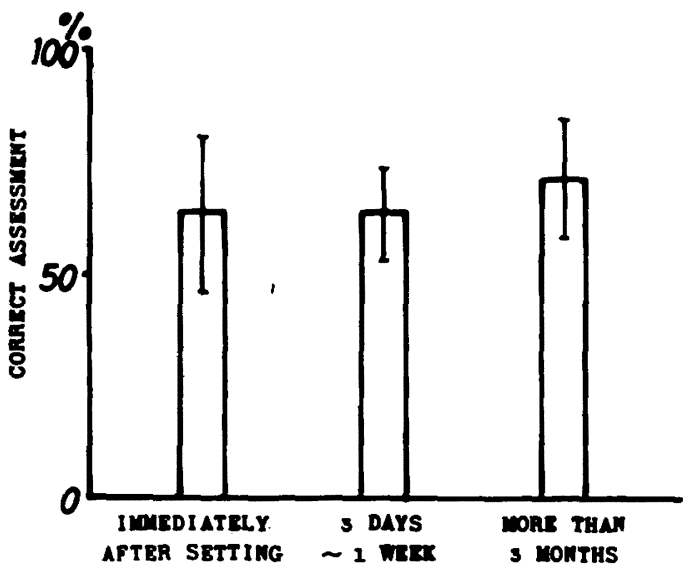

図 14 新義酱装着期閒と弁別能

新義歯装着直後から 1 週間以内では弁別能は变わらない が, 3 力月以上経過後は弁別能が高くなる。

平均正解率と標準偏差を示したものである．以上のいず れのグループも效堤状態が良好な者と不良な者が同数ず つである.

グラフに示した通り，装着直後から１週閒までは正解 率は上䄯しないが，ばらつきが少なくなる傾向が認めら れた. そして完全に義歯に慣れれば正解率が上昇する傾 向が認められたが，統計学的な有意差はなかつた。

\section{0. 新義歯と旧義歯の弁別能}

以上図 13 と図 14 に示した結果から，総義菌に対する 慣れは厚さの弁別能に影響を与える因子の1つであろう と推察できる，そこで，長く慣れ親しんだ旧義歯と，装 着直後で不慣れな新義歯との間に弁別能の差があるかど

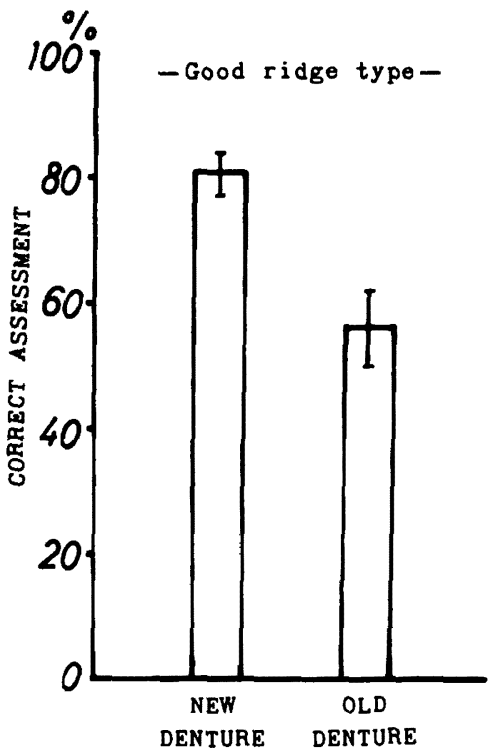

図 15 新義蒾上旧義萭の弁別能（前歯部） 新義歯の方が旧義歯より弁別能が高い.

うかを検討した.

図 15 は新義歯装着後 1 週間以内に実験を行つた影堤 状態良好な者 4 名についての結果と，同時に行つた旧義 歯の実験結果とを示す.この比較は前歯部のみで行つ た.

グラフに示したように，慣れ親しんだ旧義歯（平均装 着期間 4.62 年）よりも，むしろ装着後間もない新義歯 の方が高い正解率を示し，ばらつきも少なく，両者の間 に統計学的に有意差があつた $(\mathrm{P}<0.05)$.

図 16 は新義歯と旧義蒌の正解率を各テス卜板の厚さ 別に示したものである. いずれの厚さにおいても新義歯 の方が正解率が高かつた，新義歯も旧義歯も基準より薄 い側の方が厚い側より正解率が高い傾向が認められた。 この傾向は特に旧義菌の方が強かつた. $100 \%$ 弁別闘は 新義歯では基準より薄い側で $0.2 \mathrm{~mm}$, 厚い側で 0.3 $\mathrm{mm}$ であるのに対し，旧義蒾では基準より薄い側で 0.3 $\mathrm{mm}$ であつたが，厚い側では $0.3 \mathrm{~mm}$ の変化があつて も $100 \%$ に達しなかつた。

\section{考察}

咀嚼機能を十分発揮する義歯の理論的条件を追求する ことは歯科補緅学にとつてきわめて重要な課題である. 日常臨床において義菌装着後口腔感覚の変化を訴える患 


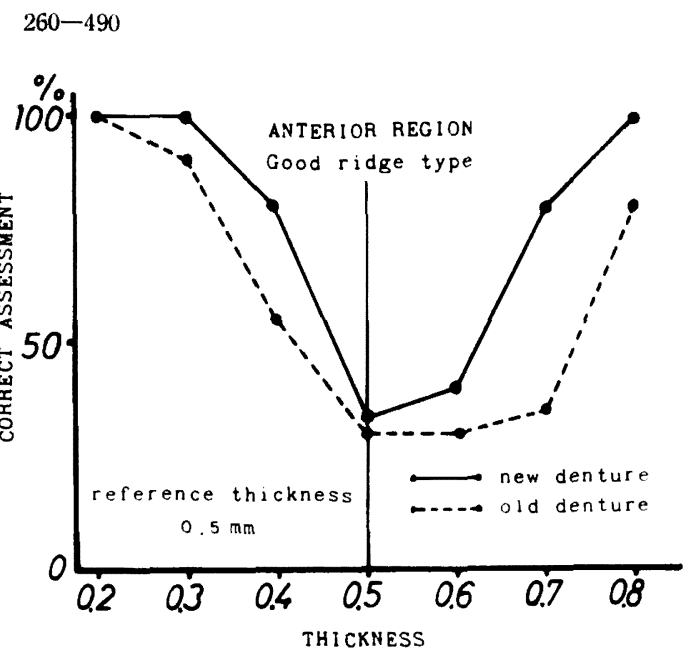

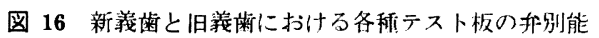

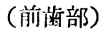

いずれのテスト板でも新義菌の方が弁別能が高い，新義菊 でも旧義蔽でも薄いテスト板の弁別能は高く，厚いテス卜 板の弁別能は低い.

者がある．そこで義歯を装着した場合の口腔感覚の変化 を正確に知る必要がある.

Manly ら) は厚さ $5.00,5.25,5.50,5.75 \mathrm{~mm}$ の 4 枚のテストを用いて実験を行い，天然歯列者，義歯装着 者, 義㐘床下に麻酔を施したものの 3 群の間に有意の差 を認めなかつた. Siirilä and Laine ${ }^{6)}$ は基準の高さを $0.03,0.5,6.0,10.0,20.0 \mathrm{~mm}$ 扩よび最大開ロー10 $\mathrm{mm}$ に変化させて開口度の違いと弁別闕の関保を調べた 結果, 義蒌装着者と天然歯列者の間に差はないと報告 した. 森本ら゙は vertical dimension $+10 \mathrm{~mm}$ および $-8 \mathrm{~mm}$ を基準として無歯影者の厚さの弁別能を調べた 結果, 弁別のパターンは天然歯列者ときわめて類似して いたと報告した. 教室の高木ら ${ }^{8}$ は基隻の高さを $15 \mathrm{~mm}$ として総義蒾装着者の厚さの弁別能在調べた結果, 義歯 装着者と天然歯列者の弁別パターンはきわめて類似し， 弁別能は総義歯装着者の方が天然歯列者に比べてやや劣 る傾向が認められたが, 統計学的な有意差はないと報告 した．渡辺 ${ }^{4,5)}$ は 0.5 5.0 $\mathrm{mm}$ までそれぞれ $0.1 \mathrm{~mm}$ 間隔仁作つたステンレス鋼線を用いて，2本の鋼線の弁 別閥とウェーバー比 $\mathrm{W}=\Delta \mathrm{R} / \mathrm{R}$ を調べた結果, 義㐘装 着者の弁別能は天然歯列者より劣るが， $\mathrm{R}$ を大きする とその差が少なくなる傾向を見出した. このように義歯 装着者の厚さの弁別能は研究者によつて異なつた報告が なされている.これは研究者によつて用いる試料や検查 法が異なるためであるうと森本 ${ }^{11}$ は述べている.しかし それ以外に, 総義菌装着者の場合, 被験者の条件や義菌
の条件を整理して実験を行つているか否かが得られた結 果に大きな影響を及ぼすと思われる.

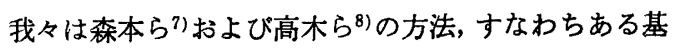
準の厚さを決め, 基準より厚い側および薄い側に 3 4 種類の異なる厚さのテスト板を設定する方法で実験を 行つた. 森本ら ${ }^{7}$ は vertical dimension $+10,-8 \mathrm{~mm}$, 高木ら ${ }^{8)}$ は $15 \mathrm{~mm}$ の厚さを基準にしたので，今回我々 は中心咬合の高さに近い $0.5 \mathrm{~mm}$ を基準として弁別能 を調べた.

本実験の結果, 厚さの弁別のパターンは総義歯装着者 と天然歯列者で差はなく，基準より薄いテスト板の方が 厚いテスト板より正解率が高く, 森本 ${ }^{11}$ の言う「方向特 異性」が明確に存在し, 森本ら ${ }^{7)}$, 高木ら ${ }^{8)}$ の報告と一致 した.この方向特異性はいずれの部位で咬んだ場合む存 在した，正解率は各部位ともに天然歯列者に比べて総義 歯装着者の場合は低下寸る傾向が認められた.これは歯 根膜の有無に起因するもの ${ }^{4)}$ とは思えず, 総義歯の動摇

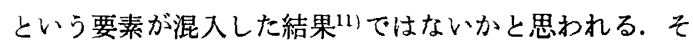
れは総義歯装着者において最も高い正解率を示した小目 歯部 $(69.8 \%)$ では, 天然歯列者の同じ部位の值 $(71.4$ \%)に近い値を示したためであり，また総義歯装着者の うちで䫑堤状態が良いグループについては小臼歯部の正 解率 $(78.0 \%)$ は天然歯列者の同部位の值よりむしろ高 かつたためである.

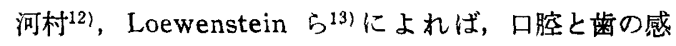
覚は口腔の前方ほど鋭敏である.このことは本実験の結 果, 天然歯列者において前歯部, 小臼歯部, 大臼歯部の 順に弁別能が高いことからも裏付けられる. しかしなが ら総義歯装着者ではこの事実はそのまま単純にはあては まらない.なぜならば義歯の維持安定が結果に影響を 及ぼすことが考えられるからである. Brillによれば (personal communication), 義歯の安定に関しては中央 $1 / 3$ の法則があてはまる. 総義歯の場合, 咬合した時最 も安定するのは，上敄第 1 小臼歯遠心 $1 / 2$ から上領第 2 大臼歯近心内斜面の部分である. したがつて, 河村 ${ }^{12)}$, Loewenstein $^{13)}$ らの示した前方ほど感覚が良いという 説は総義㐘装着者において維持安定の程度が高い中央 1/3 の部分についてのみあてはまると考えられる. 本実 験の結果, 小臼歯部が大臼歯部より弁別能が高いのは上 記の理由で説明できる. 前歯部は総義歯装着者において も本来最も弁別能が高いかもしれないが，この部分で咬 むと義歯が動摇するために弁別能が低下するのであろ う.

渡边 ${ }^{4,5)}$ は天然歯列者, 義歯装着者ともに前歯部より 
臼歯部の方が弁別能が高いと報告した．彼の実験では試 料に銅線を用い，臼歯部ではこれらを第 1 大臼歯の煩側 面渆において咬ませる方法を採用している，厚さの弁別 の実験では, 最初に基準試料を与えて, 次に判定させる 試料を与えるまでのタイムラグを出来るだけ小さくしな ければ正解率が低下する11)。つまり実験に迅速さが要求 されるわけで, 彼の方法で行つた場合, 試料のおき方や 咬み方が一定しない可能性がある，さらにまた，彼が考 察しているように前歯部の被蓋の程度にも関係があると 考えられる.すなわち，前歯部において垂直被蓋の大き い天然歯列者では，切端咬合で武料を咬ませた場合の開 口度は臼歯部で咬ませた場合より大きくなると考えられ る. Siirilä and Laine ${ }^{6)}$, 森本ら ${ }^{7,11)}$ によれば開口度が大 きくなれば弁別閥が上昇することがわかつている．した がつて, 前歯部の垂直被蓋が大きい場合, 臼歯部で晈ん だ時の開口度は前歯部で咬んだ時より小さくなり，臼歯 部の弁別能が前歯部より高いという結果になつたのでは ないかと推察出来る。

今回は総義歯を作製するとき，前歯部の垂值被葢在 $1 \mathrm{~mm}$ に規定し，しかも balanced occlusion を与えた ため, 前歯部で切端咬合させた場合, 臼歯部では cusp to cusp の接触となる. 本実験ではほぼ cusp to cusp の高さで, しかも平面で接するような咬合面板を臼歯部 に装着したため，前歯部でも臼歯部でも、テスト板を咬 んだ場合の開口度はほとんど変化していない。

また天然歯列者の場合，前歯部の垂直被蓋の少ない被 験者を選び，同様に咬合面板の厚さを調節しており，前 蒾部で咬んだ場合と歯部で咬んだ場合の開口度の差は ほとんど無視出来ると思われる，咬合面板は開口度の調 節に役立つだけではなく，陚料のおき方が容易になり， 咬み方も一定する. さらに, 実験方法の項で述べたよう に，薄いテスト板を咬ませた時，これがないと平面で接 触しないので, テスト板の弾力性あるいは硬さから厚さ を判断してしまう可能性がある. 咬合面板はこのような アーチファクトを除去するためにも必要なものである.

咬合面板を装着することによる異物感が，厚さの弁別 能を阻害する可能性がある. 総義菌装着者では異物感を 訴えた者はなかつたが天然歯列者では 3 名とも異物感を 訴えた. そこで我々はこの 3 名について咬合面板を装着 した場合としない場合の弁別能を調べてみた。この場 合, 開口度に差が生しないように，上下の咬頭がほとん ど接触する程度に愿さを調節した咬合面板を新たに作製 した. テスト板は，たわみのない $1.0 \mathrm{~mm}$ 前後のもの を使用した. 実験の結果，小臼歯部でも大臼歯部でも，
咬合面板を装着した場合と装着しなかつた場合にほとん ど差はなかつた。

また咬合面板装着による筋の疲労感は，実験時間内で は生じなかった。

以上のことから咬合面板を装着しても厚さの弁別能は 阻害されなかったと思われる.

本実験では前述したように，咬合部位の違いと弁別能 を検討することにより義歯の維持安定が厚さの弁別に影 響を及ぼすことを示唆した．しかし，この点をより明確 にするために顎堤の状態，および新義菊と旧義歯の比較 を行つた. 結果に示したように稅堤の状態の良好さを示 す Kapur の指数9) と正解率との間には正の相関関係が あり，顥堤の状態の良い者は悪い者に比べていずれの部 位で咬んだ場合も弁別能が高かつた．また，適合度の高 い新義歯の方が装着直後で慣れていないにもかかわら ず，長年使い慣れてはいるが，適合の悪くなつた旧義歯 よりも弁別能は有意に高かつた，以上のことから義歯の 維持安定は弁別能に強く影響を与えることが明らかであ る.

厚さの弁別能に性別による差があるかどうかという点 に関しては，渡辺 ${ }^{14)}$ の報告と同様差はなかつた。

年齢と厚さの弁別能との関係については，渡辺 ${ }^{14)}$ は， 高年者グループは若年者グループに比較して弁別能は劣 るが, 高年者は歯列が正常咬合であつても若年者に比べ て歯周組織に変化の可能性があるため, 増龄による感覚 機能の低下とはただちに結論出来ないと報告した．しか し厚さの弁別に歯根膜は関与しないとする報告7,11) から 考えると，歯周組織の変化が厚さの弁別能に影響を及ほ すとは考えにくい，我々の実駼結果では增龄により弁別 能が向上するような結果が得られたが，しかし，総義歯 装着者の場合は総義歯使用経験の長さ，および新義歯に 対する適応度などの要因が関与すると考えられるため， 单純に結論を引き出すことは出来ないと思われる。

本実験の結果によれば，総義歯装着者でも条件がよけ れば弁別能は天然歯列者とほとんど違わないばかりか， むしろ高い場合すらあつた。 そこで厚さの弁別能に関し ては増齢による変化は小さく，何らかの阻害要因が働く と弁別能が低下するのではないかと思われる。このよう に増㱓と感覚機能との関係は個人羑もあり, 結論がつけ 難く，今後に残された課題である．総義菌装着者に限定 して検討すれば，年齢の増加と并別能とは関倸がなく， 総義歯経験年数が強く関与するように思われる.

義菌への慣れと弁別能の関係について, 渡辺 ${ }^{5)}$ は関係 がないと述べているが, 我々の結果では, 義歯に完全に 
慣れたと判断される 3 カ月経過後に実験を行つたグルー プの正解率が装着直後から 1 週間後までの間に実験を行 つたグループの正解率より高かつたので，義歯に対する 慣れは弁別能を上昇させると考えられる。しかし慣れた 旧義歯より新義歯の正解率が高かつた結果から判断すれ ば，義歯の維持安定は義歯に対する慣れ以上に厚さの弁 別能に強い影響を持つものであると考えられる。

義歯への慣れと并別能の関係を検討する場合, 同一被 験者で新義歯装着直後から経時的に変化を調べる方法が より理想的と思われる. しかし，この種の実験は被験者 側に予備知識があれば正解率が上昇する (学習効果) 可 能性がある.これを避けようとすれば1人の被験者につ き 1 回しか実験することが出来ない，そこで我々は同人 数ずつの被験者を装着直後, 3 日から 1 週間以内, 3 力 月以上経過後の 3 グループに分けて実験を行ってみたの である、ただし，この方法で個人差によるデータのばら つきを少なくするには多数の被験者を必要とするため, 今後，引き続き被験者数を增してゆく必要があろう.

被験者の主観と実験結果の比較検討を試みることは, 感覚の実験に限らず臨床的研究においてはきわめて重要 である. 結果の項で示したように $83.3 \%$ の者が小臼歯 部において最も厚さを弁別しやすいと述べ，そのうちの $70.0 \%$ 者が実験結果でも小臼歯部の正解率が最も高 かつた. 最も弁別しやすいと答えた部位と, 実験の結果 最も正解率が高かつた部位が一致した者は顎堤状態の良 い者の $66.7 \%$ ，不良の者の $83.3 \% ，$ 全被験者では 75.0 \%であつた. つまり䫟堤状態が悪い方が安定の良い部位 を判別する能力がやや高いように思われ，これは十分予 想され得ることである.

総義菌装着者の咀嚼機能を分析した研究によれば，総 義歯装着後一定期間経過すれば咀喘值が上昇し (Vinton and Manly ${ }^{15}$ ) 1955, 辻井16) 1972), 総義歯経験のあ る人は未経験の人より咀嚼值が良いことがわかつてい る (Kapur, Soman and Stone ${ }^{17)}$ 1965. Kapur and Soman ${ }^{18)}$ 1965). 本実験の結果, 総義歯装着後一定期 間経過すれば，厚さの弁別能が上昇し，総義歯経験のあ る人は未経験の人より弁別能が高かった。 したがって, 咀嚼機能と厚さの弁別能との間には相関関倸があると推 察出来る。 さらにまた, 教室の Sasaki $ら^{19}$, 津留ら ${ }^{201}$ は実験的に上領総義菌の床の形態を変えて維持安定の程 度を変化させれば咀徱筋活動に変化が生じことを見出 した. 一方, 本実験の結果, 義歯の維持安定の良否は厚 さの弁別能に強い影響を与えることがわかつた。 つまり 総義歯の維持安定が悪くなれば口腔感覚が損われ, しか
も咀哴筋の活動に乱れが生じると考えられる，以上のこ とは咀嘒筋の活動が口腔内の感覚によつて反射的な調節 を受けているとする津留1) や長沢2) の考え方の正当性を 立証するものであろう。

本実験の結果，総義歯装着者においては，厚さの弁別 能は小歯部で最も高く，しかも被験者のほとんどが小 臼歯部が最も弁別しやすいと答えた。一方，咀嚼圧の分 担率を調べた研究によれば，硬い食品（ココナッッ，干 しぶどう)，咬みにくいと思われる食品（牛肉，乾燥あ んず）を咀礵する場合は小四歯部で咬む場合が多い (Howell and Brudevold ${ }^{21)}$ 1950, Brudevold ${ }^{22)}$ 1951). X線映画法により咀徱時の食塊の位置を調べた研究に よれば咀徱の初期においては小歯部で咬む割合が 多く，また硬い食品程，小臼歯部で咬む割合が多い (Lundberg, Wictorin and Hedegard ${ }^{23)}$ 1967). 以上 のことは小臼歯が咬断に適した形態を有しているだけで なく，総義歯で咀礵が困難であると思われるような食品 では，まず感覚の鋭敏な小臼歯部で食品の粉砕の度合い を調べながら咀嚼し，ある程度粉砕したら大臼歯部に移 して咬むのではないかと推察出来る.つまり本研究によ り総義歯では小臼歯部が重要な役割を果たすことを示唆 し得た.

従来から総義菌を装着すれば口腔感覚が損われるとい う説が主流を占めてきた. しかし, 本研究の結果, 厚さ の弁別能に関しては，機能的に優れた義歯を作製し，患 者が義歯によく適応し，巧く使いこなせるように訓練す れば，天然歯列者とほとんど同じレベルまで弁別能を向 上させ得る可能性があることがかかった.

\section{結論}

1. 総義蒾装着者の厚さの弁別のパターンは前歯部, 小臼歯部, 大臼歯部のいずれの部位でも天然歯列者との 間に差はなく，方向特異性が存在した。

2. 天然歯列者では口腔の前方歯ほど弁別能が高い が，総義歯装着者では小臼歯部が最も高かつた。

3. 総義歯装着者の厚さの弁別能は影堤の状態および 義歯の維持安定によつて強く影響を受けた.

4. 厚さの弁別能に性別による差は存在しなかつた.

5. 総義歯装着者の場合, 義歯装着期間および総義歯 経験年数が厚さの弁別能に関与し，単純に年路だけで弁 別能の良否を推定することが出来ないと考えられる.

6. 総義画装着者の厚さの弁別能は総合的に判断する と, 天然歯列者より低い傾向があるが，義歯や患者の条 
件が良好であれば天然歯列者と差のない程度まで向上さ せることが可能であると思われた.

本研究は一部文部省科学研究費（昭和 52 年度奖励A 277574） によつた.

\section{文献}

1）津留宏道：義齿機能に関する生理学的研究，I. 咬合の高 さと義歯機能との関係，口科誌，8：482 496, 1959.

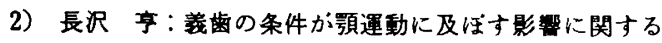
研究，国齿ジャーナル，4：609〜618，1976.

3) Manly, R.S., Pfaffman, C., Lathrop, D.D. and Keyser, J. : Oral sensory thresholds of persons with natural and artificial dentitions, J. Dent. Res., $31: 305 \sim 312$, 1952.

4）渡辺正美：口腔感覚に関する菡科学的研究，I. 天然崡と

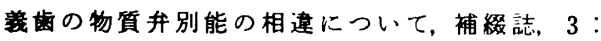
225 229, 1959.

5）渡辺正美：口腔感覚に関する電科学的研究, III. 各種義 齿で咬んだ場合の物質弁別能について, 阪大掬学誌, $7: 21 \sim 28,1962$.

6) Siirilä, H.S. and Laine, P. : Sensory thresholds in discriminating differences in thickness between the teeth, by different degrees of mouth opening, Prog. Finn. Dent. Soc., 68 : 134 139, 1972.

7）森本俊文, 尾奇雅征, 尾形和彦：無頡者における物の 大きさの弁別能, 国曾シャーナル，4:372〜373, 1976 (第23回 IADR 日本部会総会抄録).

8）高木道弘, 下永知已, 長沢 亨, 津留宏道：無菌罰者の 口腔内における立体識別之厚みの弁別に関する研究 —有雪額者との比较, 補緅誌, $22 ： 225 \sim 226,1978$ (昭 和52年度日本補緅齿科学会中国四国支部学会抄録).

9) Kapur, K.K. : A clinical evaluation of denture adhesives, J. Prosthet. Dent., 18 : 550 558, 1967.

10）高木道弘, 長沢 亨, 津留䆖道, 岡田周造：有齿頢者の 口腔内における立体識別と厚みの弁別に関する研究，広 大菡誌, $8: 133 \sim 139,1976$.

11）森本陖文：口における物の大きさの弁別, 国菊ジャー+
ル, $1: 556 \sim 565,1974$.

12）河村洋二郎：歯の感覚, 界展望, $15: 486 \sim 491,1958$.

13) Loewenstein, W.R. and Rathkamp, R. : A study of the pressoreceptive sensibility of the teeth, J. Dent. Res., 34 : 287 294, 1955.

14）渡辺正美：口腔感覚に関寸る歯科学的研究, II, 男女, 年 龄および咬合状態による物質并別能の相違について, 阪 大歯学誌, $7: 17 \sim 20,1962$.

15) Vinton, P. and Manly, R.S. : Masticatory efficiency during the period of adjustment to dentures, J. Prosthet. Dent., 5 : 477 480, 1955.

16）辻井盈子：総義装着者における咀噃様式の個人的特 性に関する生理学的観察, 口科誌, 21：127〜201, 1972.

17) Kapur, K. K., Soman, S. and Stone, K. : The effect of denture factors on masticatory performance, Part I : Influence of denture base extension, J. Prosthet. Dent., $15: 54 \sim 64,1965$.

18) Kapur, K.K. and Soman, S. : The effect of denture factors on masticatory performance, Part IV : Influence of occlusal patterns, J. Prosthet. Dent., 15 : $662 \sim 670,1965$.

19) Sasaki, H., Nagasawa, T., Tsuru, H. and Kanno, Y. : Effects of the form of the complete denture on masticatory function, J. Dent. Res., 56 (Special Issue D) 168,1977 (第24回 IADR 日本部会総会抄録).

20）津留宏道, 長沢 亨, 佐々木元: 総義齿の床の形態が咀

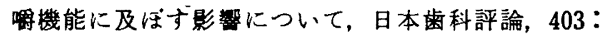
25 34, 1976.

21) Howell, A.H. and Brudevold, F. : Vertical forces used during chewing of food, J. Dent. Res., $29: 133$ $\sim 136,1950$.

22) Brudevold, F : A basic study of the chewing forces of a denture wearer, J. Am. Dent. Assoc., $43: 45 \sim 51$, 1951

23) Lundberg, M., Wictorin, L. and Hedegard, E : Masticatory function-A cineradiographic investigation II. Position of the bolus in full denture wearers, Acta Odontol. Scand., $25: 383 \sim 395,1967$. 